\title{
ENVIRONMENTAL ASPECT OF POTASSIUM BALANCE IN THE GEOGRAPHICAL AND HISTORICAL LAND OF WIELKOPOLSKA IN 1843-2012
}

\author{
Jerzy Mirosław Kupiec ${ }^{1}$ \\ 1 Department of Ecology and Environmental Protection, Poznań University of Life Sciences, Piątkowska 94C, \\ 60-649 Poznań, Poland, e-mail: jkupiec@up.poznan.pl
}

Received: 2015.09 .07

Accepted: 2015.10.06

Published: 2015.11.10

\begin{abstract}
The aim of the study was to assess the intensity of potassium management in agriculture, on the basis of field surface balance in the changing boundaries of Wielkopolska region, with its capital in Poznań. 14 periods were selected at the turn of three centuries XIX, XX and XXI. The surface area and the administrative boundaries have changed quite considerably during this period. Potassium is one of the most important elements which is of great importance not only in the nutrition of crops, but also in human and animal nutrition. Its impact on the environment is not yet fully known. However, agricultural production generates a surplus of this macronutrient, which can be dispersed in the environment. The calculated potassium balance depended largely on the economic and political situation and administration, which affect the degree of intensification of agricultural production in the region. The balance results ranged from -45.47 to $129.71 \mathrm{~kg} \mathrm{~K} \cdot \mathrm{ha}^{-1}$ per agricultural land. By 1955 , the balance of potassium showed negative values. After this period, the balance recorded was only positive.
\end{abstract}

Keywords: potassium balance, non-point pollution, Wielkopolska's agriculture, agrienvironmental indicators.

\section{INTRODUCTION}

Research on the history of agriculture, having a long and good tradition in Polish historical literature, did not so far include issues related to the scale of production in farms and the degree of risk to the environment over the centuries. Although the interest in former agriculture often occurred, it was rarely spoken about the environmental aspects of these considerations. Currently reflections on agriculture have multidimensional nature that combines social, economic and environmental aspects. However, they include current issues and rarely cover comparison to the old farming. Potassium is one of the most important elements which are of great importance not only in the nutrition of crops, but also in human and animal nutrition [Rodewyk 1979, Mendra and Barszczewski 2013]. Its impact on the environment is not yet fully known. In addi- tion to taking potassium from the soil by plants, much of it is lost from agricultural production due to erosion. A large amount of this element in the soil comes from the bedrock. Much less potassium is brought into the soil environment with mineral fertilizers, natural or organic. Very small amount of the nutrient enters the soil as a result of deposition. Potassium uptaken by crops should be immediately supplemented. The basis of supplementation of this component is mineral fertilization, which is an important yielding factor and has an important position in the structure of direct costs of agricultural production [Kopiński 1999].

The aim of the study was for the purpose of assessing the intensity of potassium management in agriculture in terms of diffuse pollution monitoring based on the field surface balance in the changing boundaries of the Wielkopolska region, with its capital in Poznań. 


\section{MATERIAL AND METHODS}

Agricultural data. Information about the structure of animal species and their abundance, structure of land use and crops, crop yield and fertilizers use were obtained by the practitioners development, agricultural activists, scribes and statistical studies [Ziemianin... 1850, Grabski 1914, 1915, Strasburger 1916, Romer and Weinfeld 1917, Rocznik... 1923, Tablice... 1923, Tablice... 1927, Mały Rocznik... 1931, Mały Rocznik... 1935, Mały Rocznik... 1939, Mały Rocznik... 1948, Rocznik... 1949, Rocznik... 1950, Rocznik... 1956, Tablice... 1956, Rocznik... 1964, Rocznik... 1973, Rocznik... 1983, Rocznik... 1993, Historia... 1994, Rocznik... 2003, Rocznik... 2013, Kuklo et al. 2014]. Analyses were made for years and the most complete and accurate data were collected.

Potassium sheet balance. The correctness of the potassium management was calculated based on the field surface balance [Kupiec and Zbierska 2012]. Some of the elements of balance structure were significant only at certain times. Later due to changes in agricultural techniques, but also introduced legislative acts, their share decreased or completely lost its importance. Potassium balance formula is as follows:

$$
\begin{gathered}
\mathrm{K}_{\text {budget }}=\Sigma \mathrm{K}_{\mathrm{F}}+\Sigma \mathrm{K}_{\mathrm{M}}+\Sigma \mathrm{K}_{\mathrm{S}}+\Sigma \mathrm{K}_{\mathrm{W}}+\Sigma \mathrm{K}_{\mathrm{L}}+ \\
+\Sigma \mathrm{K}_{\mathrm{A}}-\Sigma \mathrm{K}_{\mathrm{C}}-\Sigma \mathrm{K}_{\mathrm{G}}
\end{gathered}
$$

where: $\mathrm{F}$ - fertilizers, $\mathrm{M}$ - solid manure, S - slurry, W - faecal/domestic waste water, $\mathrm{L}$ - forest litter, A - woody ash, $\mathrm{C}-$ crops, $\mathrm{G}-$ yield of grassland

The potassium balance sheet formula took into account historical conditions and cultivated agricultural practices in an individual period. The nutrient content was based on the results of chemical analyses and researchers experiments of the period.

Mineral fertilizers. Due to the low interest of fertilizers in the nineteenth century and their marginal rate, omitted this part of the balance sheet for the years 1943 and 1873. In other periods, the amount of potassium from fertilizers calculated on the basis of their consumption in the region. Because of the lack of data for the years 1922 average consumption of fertilizers for the Polish territory from that period was assumed, increased by average higher consumption in the region (19\% more).

Manures. In the nineteenth century and the first half of the twentieth century, the handling of liquid manures was irrational and they were used in marginal extent. Therefore, for 1938, the income was calculated only for potassium from produced solid manure. The quantity of manure produced by livestock was calculated according to Górski [by Niklewski 1949]. The amount of potassium in the manure produced in this period was calculated by Mayer [by Niklewski 1949]. The amount of resulting manure in period of 1843-1955 was calculated based on Haselhoff [by Niklewski 1949] and Górski [1947]. The amount of manure produced in the period 1961-2012 was calculated according to guidelines of Council of Ministers from 18 May 2005 [Rozporządzenie... 2005]. Potassium content in manure produced in this period was calculated by Mazur and Górski [by Wrześniowski et al. 1997].

Straw and forest litter. In the twentieth century when straw was insufficient, forest litter was often used as bedding for animals. Due to the situation of agriculture in this period, materials for which there was no need to pay for were mainly used. Peat was too expensive so it was marginally used as a bedding. The first regulations restricting this type of procedure that adversely affected the functioning of forest ecosystems, were introduced at the beginning of the twentieth century. In this paper the amount of used forest litter was counted based on the difference between the amount of straw harvested from the fields and the needs of the animals in this area [Stutzer 1902].

The amount of straw produced in the fields was calculated based on the proportion of main crop to a by-product. The proportions were calculated on the basis of the average yield of grain and straw given by Stutzer [1902]. They amounted for rye $1: 4$, wheat $1: 2$, barley $1: 1.3$, oats $1: 1.8$. Straw harvested from the fields is calculated on the basis of the information given by Kostrowicka et al. [1984]. Farmers living in the nineteenth century in the region of the Grand Duchy of Poznan cut the spikes by hand, with sickles. The rule was cut straw as high as possible, so the vast majority of the straw remained on the field. In the first half of the twentieth century agriculture in the region experienced a significant modernization. The introduction of new machinery and equipment, including harvesting of cereals, also resulted in a greater yield of straw, which was useful in the intensification of animal production. Therefore, the article assumes that farmers harvested approximately $1 / 4$ part of straw in 1843 and 1873 and $1 / 2$ in 1912. The demand for bedding for livestock was calculated based on the individual needs of each species 
[Stutzer 1902]. The contents of the nutrient in the forest litter was calculated by Niklewski [1949].

Faecal. In the nineteenth century people did not pay much attention to the storage of domestic sewage and mostly collected them in bare earthen pits, thereby liquid manures penetrated into the soil. However, they were an important element of fertilization in some farms. For the period 19431912 only the amount of hard excrements was calculated according to the information given in Ziemianin [1850]. The sum of the faeces was calculated for a rural population living in this region in a particular periods. The potassium content in solid faecal was calculated by Stutzer [1902].

The amount of human faeces used as a fertilizer in 1921-1946 and the content of potassium was calculated by Stutzer [1902]. Other authors also reported that human faeces are an excellent potassium fertilizer [F.R. Rolnik Nadwiślański 1900]. However, in subsequent periods faeces ceased to be used as fertilizer, and therefore, they are not included in the balance sheet components.

Woody ash. Ash in the nineteenth and early twentieth century was often used as a fertilizer. The nutrient made this way, dated 1843 to 1931 was calculated. In subsequent years, they have ceased to be valuable as a fertilizer and rather treated them in terms of waste. The amount of wood spent as fuel in farms, in the analysed periods were calculated based on the average consumption of firewood [Zużycie... 2012]. Potassium content in the ash was calculated by GaerdtaLobner [by Niklewski 1949].

\section{RESULTS AND DISCUSSION}

\section{The characteristic of Wielkopolska region}

The area of research is located in the geographical and historical land of Wielkopolska, with its capital in Poznań, within the changing administrative borders (Figures 1-4). Wielkopolska is a region that has marked strongly in the history of Poland and is strongly associated with the onset of Polish statehood [Topolski 1969, Włodarczyk 2012]. The nineteenth century is a special period in the history of Poland because it has lost its identity as a result of the three partitions made by Austria, Prussia and Russia in 1769, 1793 and 1795. During the second partition, Prussia took over, inter alia Gniezno Province, Poznań, Kalisz and the land of Wielun associated with Wielkopolska region [Baranowski and Topolski 1964].
The result of partition was the acquisition of $20 \%$ of Poland territory by Prussia. Austria has acquired $18 \%$ of the area. Russia took over the largest part, because $62 \%$ of the old Republic. Prussian sector, including Wielkopolska region, was inhabited mostly by the Polish population and took incomparably better economically developed land. All the countries partitioning remained a feudal system and the supremacy of the nobility over the village. In Prussia and Austria, however, partly attempted to reform the feudal relations.

In the analysed period several periods affecting Wielkopolska region and developing agriculture can be distinguished [Baranowski and Topolski 1964, Kostrowicka et al. 1984, Kraciński 2011]: a) 1807 - the creation of the Duchy of Warsaw. Duchy of Poznan has become the one of the six departments; b) 1815 - the creation of the Grand Duchy of Poznań; c) 1848 - liquidation of the Grand Duchy of Poznań and the formation of the Poznan Province; d) the second half of the nineteenth century - the progress of agriculture in the Prussian partition was the largest of the occupied lands. More efficient and rational farming systems and new agrotechnical methods began to be introduced there. Of all the occupied lands, in the Duchy of Poznan the three-field system was abandoned the earliest; e) 1882-1895 - increase in the number of farms which used the agricultural machinery in Poznań area from 10 to $43 \%$, f) 1902 - in Poznań area the electric motor was first used in agriculture. Also the consumption of mineral fertilizers began to increase. In 1906, $1185 \mathrm{~kg}$ of potassium salts per 100 hectares of agricultural land were used, while the national average was $786 \mathrm{~kg}$, g) 1914-1918 - World War I; h) 1918/1919 - won Wielkopolska Uprising enabled the connection the Poznan Province to the Republic of Poland; i) 1929-1933 - global crisis, which also took agriculture due to agrarian overpopulation; j) 1939-1945 - World War II. Poznań voivodeship became part of one from the two counties - Reischsgau Wartherland, initially called Reichsgau Posen. In October 1939, the Germans removed a significant amount of peasants and farm owners from farms in the Poznań voivodeship. Colonization was carried out at the same time to place the displaced population, in District Warta most marked - in the Poznań and Łódź voivodeships; k) 1945-1955 - the creation of State Agricultural Farms and cooperatives, eliminated the remnants of the feudal system, parcelling out farms; 1) 1955 -implementation of the 


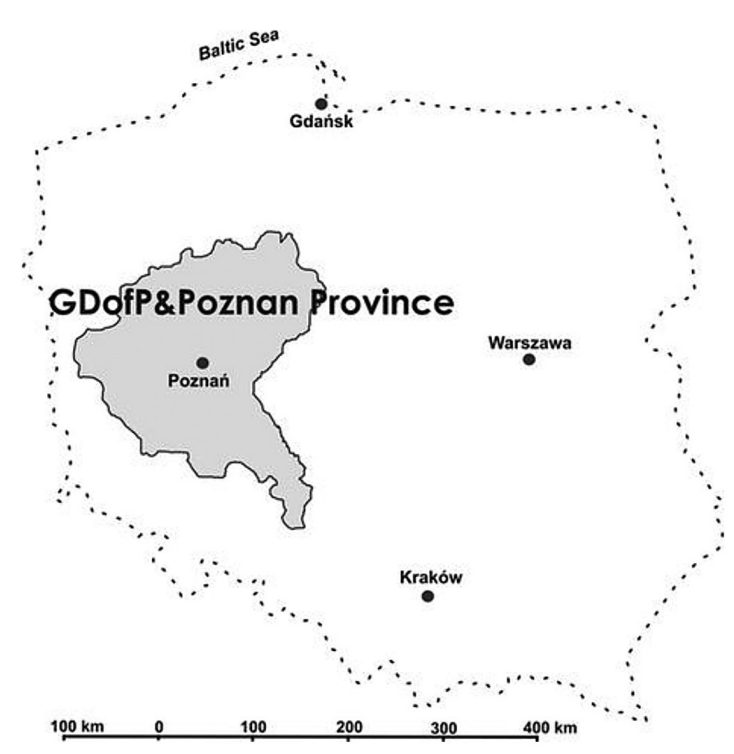

Figure 1. Border of Grand Duchy of Poznań (18151848) and Poznań Province (1848-1919) in the background of the current Polish border

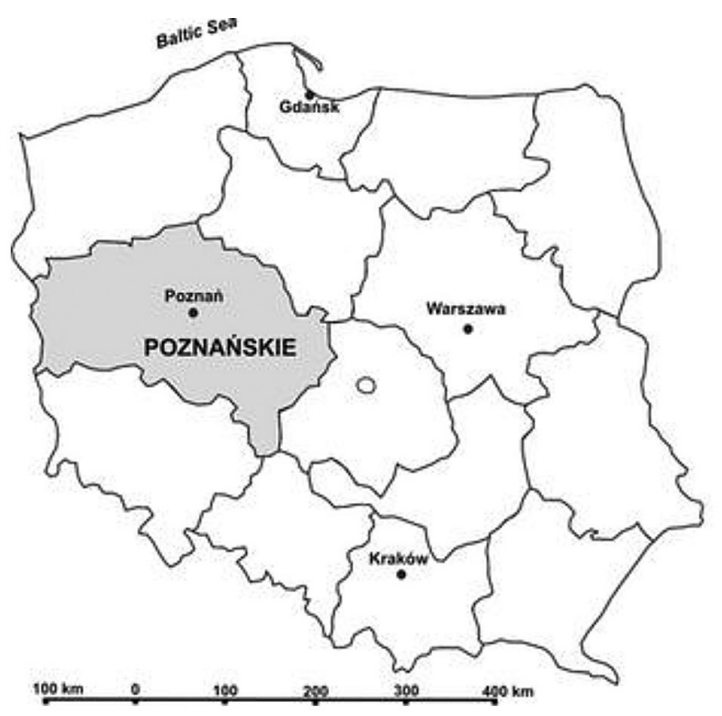

Figure 3. Border of Poznańskie voivodeship in 1946-1950 and 1950-1975
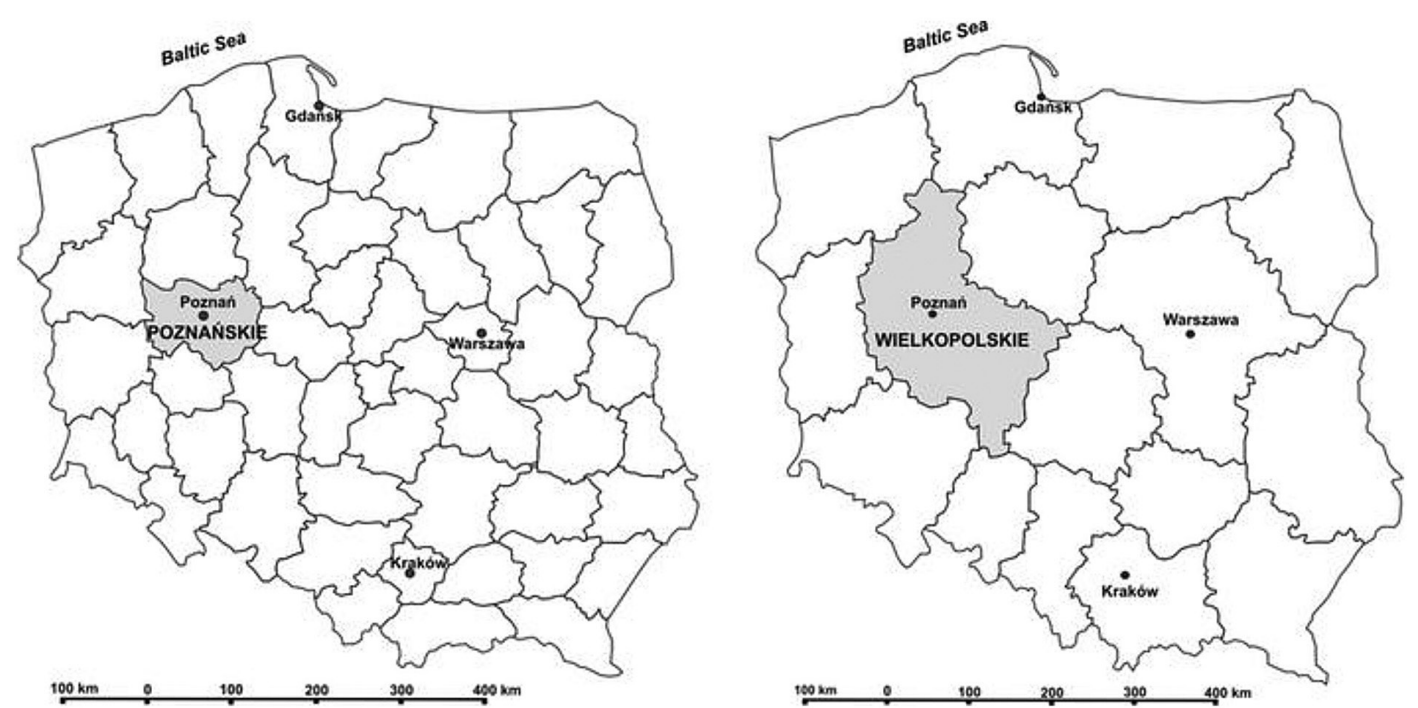

Figure 4. Border of Poznańskie voivodeship in 1975-1998 and Wielkopolskie voivodeship in 1998-2014 
five-year remedial plan, m) 1960 - introduction of agro-minimum; n) 1970's - agriculture was freed from many injunctions and charges; o) 1980 - economic crisis; p) 1989 - the collapse of the communist system and the elimination of large-scale, socialized farms; r) 1991 - the establishment of the Agricultural Property Agency of the Treasury, renamed in 2003 for Agricultural Property Agency and the beginnings of distribution assets of State Agricultural Farms; s) 1999 - the development of the so-called Pact for the village, which included, among others, supporting agriculture and its environment, entrepreneurship and the creation of non-agricultural jobs; t) 2004 - Polish accession to the European Union and the beginnings of multifunctional rural development.

Wielkopolska region was at the forefront in terms of technology and agricultural productivity throughout the considered period. The area of the region examined ranged from 815097 in 1992 to 3950300 ha in 1947 (Table 1). The land structure clearly marked with a dominance of agricultural land, including arable land. In the period of 18432014 the surface was reduced by approximately $16 \%$. Major changes took place mainly in the area of permanent grassland, which decreased from 34.2 in 1843 to $8.4 \%$ in 2012 . Dated $1871-1961$ the share of meadows and grassland remained at a similar level (approximately 10.5\%). The smallest share of permanent grassland was observed in 1992, which was associated with political changes in Poland and the liquidation of State Agricultural
Farms and Agricultural Production Cooperatives, with a considerable amount of cattle. The share of forest area in the region of Wielkopolska ranged from 17.4 to $25.7 \%$. Shortly after World War II Wielkopolska Province has gained in forestation through the lands attached from Lubuskie Province. The forest area in 1947 was $24.1 \%$ (Table 1).

Analysing the share of individual plant groups in the structure of crop, the share of cereals in crop structure underwent a fairly large fluctuations of up to $30 \%$ (Table 2). It is worth to note that even in the nineteenth century legumes were grown on large areas, which formed the basis of food, but also animal feed. In the twentieth century in the areas under these crops in the region of Wielkopolska strongly decreased and this situation has remained to this day. Root crops, including potatoes, almost did not matter in the nineteenth century. In the second half of the nineteenth century there was an increase in the acreage of potatoes and sugar beets crops. Root crops occupied large cultivated areas, mainly in the interwar period (Table 2). Currently root crops constitute a small share in the sowing structure. Growing state after World War II quickly returned to normal.

The number of animal species kept in farms in Wielkopolska region has changed over time. The population of horses remained at relatively equal level in the period 1843-1961 (Table 3). In the later period, the number of horses in the region has decreased dramatically. This was mainly associated with increased mechanization

Table 1. Land use structure in particular periods

\begin{tabular}{|c|c|c|c|c|c|c|c|}
\hline Year & $\begin{array}{l}\text { Area of the } \\
\text { region }\end{array}$ & $\begin{array}{l}\text { Agricultural } \\
\text { land }\end{array}$ & \begin{tabular}{|c|}
$\begin{array}{c}\text { Arable land with } \\
\text { orchards and } \\
\text { gardens }\end{array}$ \\
\end{tabular} & Meadows & Pastures & $\begin{array}{l}\text { Woods. forests } \\
\text { and woodlots }\end{array}$ & $\begin{array}{c}\text { Other land and } \\
\text { wasteland }\end{array}$ \\
\hline & [ha] & \multicolumn{6}{|c|}{ [\%] } \\
\hline 1843 & 2987010 & 74.8 & 40.6 & 14.1 & 20.1 & 20.5 & 4.7 \\
\hline 1873 & 2895239 & 74.9 & 61.6 & 8.1 & 5.2 & 20.2 & 4.9 \\
\hline 1912 & 2899000 & 75.0 & 64.6 & 7.8 & 2.6 & 18.1 & 6.9 \\
\hline 1921 & 2657929 & 76.0 & 65.6 & 7.8 & 2.6 & 18.1 & 5.9 \\
\hline 1931 & 2835000 & 75.1 & 64.6 & 7.1 & 3.4 & 17.4 & 7.5 \\
\hline 1939 & 2835000 & 75.1 & 64.6 & 7.1 & 3.4 & 17.4 & 7.5 \\
\hline 1946 & 3950300 & 67.8 & 57.4 & 7.5 & 2.8 & 24.1 & 8.1 \\
\hline 1955 & 2744300 & 69.9 & 59.0 & 6.9 & 4.0 & 19.8 & 10.3 \\
\hline 1961 & 2672269 & 70.5 & 59.7 & 7.0 & 3.9 & 21.7 & 7.8 \\
\hline 1972 & 2684885 & 66.7 & 55.7 & 7.8 & 3.2 & 23.6 & 9.7 \\
\hline 1982 & 822757 & 66.4 & 58.6 & 5.7 & 2.2 & 20.9 & 12.7 \\
\hline 1992 & 815097 & 66.2 & 58.6 & 5.4 & 2.2 & 21.1 & 12.7 \\
\hline 2002 & 2982559 & 59.6 & 51.2 & 6.8 & 1.5 & 25.7 & 14.7 \\
\hline 2012 & 2982559 & 58.8 & 50.4 & 7.6 & 0.8 & 25.7 & 15.5 \\
\hline
\end{tabular}


Table 2. Structure of crops in investigated periods

\begin{tabular}{|c|c|c|c|c|c|c|}
\hline \multirow{2}{*}{ Year } & Cereals & Fabaceae & Industrial and special plants & Forage crops & Root plants & Others \\
\hline & \multicolumn{6}{|c|}{ [\%] } \\
\hline 1843 & 80.3 & 17.0 & 0.8 & 0.0 & 0.6 & 1.3 \\
\hline 1873 & 71.3 & 17.6 & 0.7 & 0.6 & 9.1 & 0.7 \\
\hline 1912 & 63.4 & 4.6 & 0.0 & 7.3 & 20.0 & 4.6 \\
\hline 1922 & 69.7 & 0.0 & 0.0 & 0.0 & 30.3 & 0.0 \\
\hline 1931 & 71.8 & 1.5 & 0.2 & 0.0 & 26.4 & 0.1 \\
\hline 1938 & 73.8 & 1.1 & 0.9 & 0.0 & 24.1 & 0.0 \\
\hline 1946 & 66.0 & 2.4 & 2.6 & n.d. & 17.2 & 11.8 \\
\hline 1955 & 50.9 & n.d. & n.d. & n.d. & 22.6 & 26.5 \\
\hline 1961 & 53.5 & 0.5 & 2.4 & 15.8 & 25.6 & 2.2 \\
\hline 1972 & 60.9 & 5.7 & 3.3 & 0.0 & 28.0 & 2.2 \\
\hline 1982 & 50.3 & 9.1 & 3.5 & 10.6 & 22.1 & 4.4 \\
\hline 1992 & 56.6 & 7.8 & 7.2 & 6.8 & 16.1 & 5.5 \\
\hline 2002 & 79.0 & 2.1 & 5.7 & 0.0 & 10.5 & 2.8 \\
\hline 2012 & 70.0 & 3.8 & 7.4 & 7.9 & 7.3 & 3.5 \\
\hline
\end{tabular}

Table 3. Structure of animal species in analysed periods

\begin{tabular}{|c|c|c|c|c|c|c|}
\hline \multirow{2}{*}{ Year } & Horses & Cattle & Swine & Sheep \& goats & Poultry \& rabbits & \multirow{2}{*}{ Summary LSU $=100 \%$} \\
\hline & \multicolumn{5}{|c|}{ [\%] } & \\
\hline 1843 & 23 & 54 & 4 & 17.3 & 2.4 & 761720 \\
\hline 1871 & 21 & 45 & 4 & 27.5 & 2.4 & 1027499 \\
\hline 1912 & 25 & 59 & 10 & 2.8 & 2.4 & 1291512 \\
\hline 1922 & 23 & 62 & 9 & 3.5 & 2.4 & 1135712 \\
\hline 1931 & 27 & 58 & 11 & 2.3 & 2.4 & 1222246 \\
\hline 1938 & 26 & 59 & 10 & 2.7 & 2.4 & 1594893 \\
\hline 1946 & 29 & 55 & 10 & 3.0 & 2.0 & 998343 \\
\hline 1955 & 24 & 55 & 16 & 2.2 & 3.1 & 1140980 \\
\hline 1961 & 22 & 55 & 18 & 3.0 & 1.6 & 1241843 \\
\hline 1972 & 16 & 54 & 26 & 2.5 & 0.9 & 1403648 \\
\hline 1982 & 6 & 52 & 37 & 4.4 & 1.3 & 485248 \\
\hline 1992 & 5 & 41 & 51 & 2.4 & 1.0 & 438105 \\
\hline 2002 & 2 & 55 & 29 & 0.6 & 14.0 & 1320250 \\
\hline 2012 & 2 & 50 & 31 & 0.4 & 16.4 & 1200834 \\
\hline
\end{tabular}

of agriculture. In the reviewed period sheep and goats decreased significantly from approximately $28 \%$ to the marginal amount. Swine, which in the nineteenth century accounted for only $4 \%$ of the inventory, in the twentieth century has gained in importance. In the analysed period the share of swine in inventory increased to $51 \%$ (Table 3 ).

\section{Potassium balance}

Potassium balance results for the region in the years 1843-2012 vary over a wide range from -45.47 to $129.71 \mathrm{~kg} \mathrm{~K} \cdot \mathrm{ha}^{-1}$ UR (Table 4). In the period 1843-1955 there was a negative balance. Since 1961 there has been a positive balance, which was caused by using mineral fertilizers and manures in large amounts. Very high balance of this nutrient occurred in 1972 and 1982. It was when fertilization was the highest, which also resulted the higher fertilization in Poland [Grzebisz et al. 2004]. Although potassium fertilization in the early 1990's decreased, a collection of this macronutrient from field remained at a similar level. This reflects the changes in the management of fertilizers, resulting from regulations on environmental standards and recommendations for farmers. 
Table 4. Structure of potassium balance in farms of Wielkopolska region in analysed periods

\begin{tabular}{|c|c|c|c|c|c|c|c|c|c|c|c|}
\hline \multirow{3}{*}{ Year } & \multicolumn{7}{|c|}{ Input [kg K·ha $\left.{ }^{-1} \mathrm{AL}\right]$} & \multicolumn{3}{|c|}{ Output $\left[\mathrm{kg} \mathrm{K} \cdot \mathrm{ha}^{-1} \mathrm{AL}\right]$} & \multirow{3}{*}{ Balance } \\
\hline & \multirow{2}{*}{$\begin{array}{c}\text { Mineral } \\
\text { fertilizers }\end{array}$} & \multicolumn{2}{|c|}{ Manures } & \multirow[b]{2}{*}{ Faecal } & \multirow{2}{*}{$\begin{array}{l}\text { Woody } \\
\text { ash }\end{array}$} & \multirow{2}{*}{$\begin{array}{c}\text { Forest } \\
\text { litter }\end{array}$} & \multirow{2}{*}{$\begin{array}{l}\text { Summary } \\
\text { input }\end{array}$} & \multirow[b]{2}{*}{ Crops } & \multirow{2}{*}{$\begin{array}{c}\text { Sward } \\
\text { from } \\
\text { grassland }\end{array}$} & \multirow{2}{*}{$\begin{array}{c}\text { Summary } \\
\text { output }\end{array}$} & \\
\hline & & $\begin{array}{l}\text { solid } \\
\text { manure }\end{array}$ & slurry & & & & & & & & \\
\hline 1843 & - & 3.71 & - & 0.36 & 0.67 & 0.44 & 5.18 & 1.47 & 23.63 & 25.10 & -19.92 \\
\hline 1871 & - & 4.68 & - & 0.45 & 0.85 & 0.10 & 6.08 & 41.67 & 9.88 & 51.55 & -45.47 \\
\hline 1913 & 1.97 & 7.34 & - & 0.54 & 1.02 & 1.14 & 12.01 & 22.88 & 8.12 & 31.01 & -19.00 \\
\hline 1922 & 0.60 & 6.60 & - & 0.54 & 1.01 & - & 8.75 & 14.42 & 7.92 & 22.34 & -13.58 \\
\hline 1931 & 3.85 & 7.07 & - & 0.65 & 1.22 & - & 12.79 & 16.56 & 7.89 & 24.45 & -11.66 \\
\hline 1938 & 2.62 & 9.07 & - & 0.65 & - & - & 12.34 & 14.29 & 7.89 & 22.18 & -9.84 \\
\hline 1946 & 5.46 & 4.83 & 0.63 & 0.64 & - & - & 11.57 & 26.89 & 20.16 & 47.05 & -35.48 \\
\hline 1955 & 22.24 & 7.83 & 1.02 & - & - & - & 31.10 & 43.69 & 9.40 & 53.09 & -21.99 \\
\hline 1961 & 23.82 & 30.46 & 23.29 & - & - & - & 77.57 & 27.47 & 6.78 & 34.26 & 43.31 \\
\hline 1972 & 66.32 & 38.90 & 33.31 & - & - & - & 138.53 & 36.66 & 8.74 & 45.40 & 93.13 \\
\hline 1982 & 104.00 & 36.01 & 38.14 & - & - & - & 178.14 & 40.16 & 8.27 & 48.43 & 129.71 \\
\hline 1992 & 21.50 & 44.61 & 40.93 & - & - & - & 107.04 & 34.61 & 5.73 & 40.34 & 66.70 \\
\hline 2002 & 19.01 & 27.34 & 34.25 & - & - & - & 80.60 & 30.43 & 9.85 & 40.28 & 40.32 \\
\hline 2012 & 31.87 & 22.44 & 26.76 & - & - & - & 81.07 & 47.90 & 11.19 & 59.09 & 21.98 \\
\hline
\end{tabular}

In 1843 there was low potassium harvested with crops (Table 4). Potassium is present in the older parts of the plant. A lot of it is in straw. During this period, however, little straw was harvested. In addition, one-third of the arable land was removed from service annually due to the threefield applied then. In the analysed year high set of potassium from grassland is noticeable. The share of grassland in the structure of agricultural land was significant. Meadow-pasture economy in this period was a very important chapter in the farms of the period. After World War II in 1946, increased potassium collection from grassland. This was mainly due to the change in the boundaries of the region, which included lands now belonging to the province of Lubuskie. Grasslands were characterized by probably higher yield, but also much more intensively exploited areas. It was a period when a very large number of animals was delivered to farmers, as compensation for the lost population during the Second World War. For feeding, fodder was needed. In addition, agriculture was also heavily mechanized, which allowed for intensive use of meadows.

Wielkopolska soils in available potassium looks much worse than in the case of phosphorus. However, a large part of the region is deficient in this component. In this case, the optimal balance would be a value indicating a small surplus of about $15 \mathrm{~kg} \mathrm{~K} \cdot \mathrm{ha}^{-1} \mathrm{UR}$. Following Toczyński et al. [Toczyński et al. 2013] the scope of opti- mal balance for potassium in Wielkopolska region is about $12.8-17.8 \mathrm{~kg} \mathrm{~K} \cdot \mathrm{ha}^{-1} \mathrm{UR}$. Analysing this balance it may be noted that since 1961 potassium balance has been high for the terms and conditions of Wielkopolska. Previously, there was based mainly on manure as a source of nutrients [Ziemianin... 1850, Godlewski 1901, Langie 1920]. Other elements of the income as faeces, woody ash or forest litter had little significance as an input of potassium. Thus, the balance reached a value below zero.

\section{CONCLUSIONS}

Potassium balance for farms located in Wielkopolska in the nineteenth century and the mid-twentieth indicated a deficit of this macro component in agricultural production. From an environmental point of view, it was a favourable situation because of the absence of the nutrient surplus and risk of dispersal potassium in the environment. Extensive agricultural economy based mainly on manure as a source of soil nutrients favoured sustainable crop production. Economic and political situation in the region also influenced the balance fluctuations in this period. Intensification of agriculture after World War II, the introduction of reforms aimed at increasing agricultural productivity, but also improving the standard of living of the rural population, contributed to a significant increase in the balance 
of potassium. The increase in the consumption of mineral fertilizers and not frugal agricultural economy emerged not only new environmental problems, but also the economic problems, noticeable in the 1990's. Agriculture of Wielkopolska region, focused solely on maximizing profit, bypassing the environmental aspects, exceed the recommended environmental standards. This was mainly caused by a lack of appropriate legislation in this area, which came into effect only at the end of the twentieth century.

\section{REFERENCES}

1. Rodewyk A. 1979. Information über Kali. Ratgeber für die Landwirtschaft. No 4. Kali und Salz AG Kassel, 128.

2. Mendra M. and Barszczewski J. 2013. Gospodarka potasem w warunkach zrównoważonego nawożenia na łące trwałej nawadnianej oraz bez nawodnień. Journal of Research and Applications in Agricultural Engineering, 58(4).

3. Kopiński J. 1999. Uproszczony bilans składników nawozowych w gospodarstwach indywidualnych o różnej intensywności. Rocz. Nauk. Roln. Seria G, 88, 1, 127-139.

4. Ziemianin. Pismo poświęcone rolnictwu i przemysłowi. Tom I. 1850. Nakładem Redakcyi. (Ed.) W. A. Wolniewicz (1779-1852). Poznań, 376.

5. Grabski W. 1914. Rocznik Statystyczny Królestwa Polskiego. Druk Piotra Laskauera w Warszawie. Warszawa, 187.

6. Grabski W. 1915. Rocznik Statystyczny Królestwa Polskiego. Druk Piotra Laskauera w Warszawie. Warszawa, 173.

7. Strasburger E. 1916. Rocznik Statystyczny Królestwa Polskiego z uwzględnieniem innych ziem polskich. Wyd. Drukarnia Naukowa w Warszawie. Warszawa, 178.

8. Romer E. and Weinfeld I. 1917. Rocznik Polski. Tablice Statystyczne. Drukarnia Uniwersytetu Jagiellońskiego. Kraków, 104.

9. Rocznik Statystyki Rzeczypospolitej Polskiej 1920/22. (1923). Główny Urząd Statystyczny. Druk L. Bogusławskiego. Warszawa, 403.

10. Tablice Statystyczne 1923 (1923). Instytut Wydawniczy „Bibljoteka Polska”. Warszawa-Bydgoszcz, 111.

11. Tablice Statystyczne za lata 1925 i 1926 (1927). Nakład Księgarni F. Hoesicka. Warszawa, 103.

12. Mały Rocznik Statystyczny 1930 (1931). Główny Urząd Statystyczny Rzeczypospolitej Polskiej. Warszawa, 49.

13. Mały Rocznik Statystyczny 1934 (1935). Głów- ny Urząd Statystyczny Rzeczypospolitej Polskiej. Warszawa, 42.

14. Mały Rocznik Statystyczny 1939 (1939). Główny Urząd Statystyczny Rzeczypospolitej Polskiej. Warszawa, 424.

15. Rocznik Statystyczny 1947 (1948). Główny Urząd Statystyczny Rzeczypospolitej Polskiej. Zakł. Graficzne Państwowych Zakładów Wydawnictw Szkolnych. Bydgoszcz, 113.

16. Rocznik Statystyczny 1948 (1949). Główny Urząd Statystyczny. Zakł. Graficzne Państwowych Zakładów Wydawnictw Szkolnych. Bydgoszcz, 291.

17. Rocznik Statystyczny 1949 (1950). Główny Urząd Statystyczny Rzeczypospolitej Polskiej. Zakł. Graficzne Państwowych Zakładów Wydawnictw Szkolnych. Bydgoszcz, 339.

18. Rocznik Statystyczny 1955 (1956). Główny Urząd Statystyczny Polskiej Rzeczypospolitej Ludowej. Drukarnia im. Rewolucji Październikowej. Warszawa, 287.

19. Tablice Statystyczne 1953-1954 (1956). Główny Urząd Statystyczny Polskiej Rzeczypospolitej Ludowej. Warszawa, 93.

20. Rocznik Statystyczny Województwa Poznańskiego (1964). Urząd Statystyczny dla m. Poznania i Województwa Poznańskiego. Poznań, XVIII, 337.

21. Rocznik Statystyczny Województwa Poznańskiego. (1973). Urząd Statystyczny. Poznań: 467.

22. Rocznik Statystyczny Województwa Poznańskiego (1983). Wojewódzki Urząd Statystyczny. Poznań, 333.

23. Rocznik Statystyczny Województwa Poznańskiego (1993). Wojewódzki Urząd Statystyczny. Poznań, 295.

24. Historia Polski w liczbach. Ludność, terytorium. (1994). Główny Urząd Statystyczny. Zakład Wydawnictw Statystycznych. Warszawa. 205.

25. Rocznik Statystyczny Województwa Wielkopolskiego (2003). Urząd Statystyczny w Poznaniu. Poznań, 421.

26. Rocznik Statystyczny Województwa Wielkopolskiego (2013). Urząd Statystyczny w Poznaniu. Poznań, 433.

27. Kuklo C., Łukasiewicz J., Leszczyńska C. 2014. Historia Polski w liczbach. Polska w Europie. Główny Urząd Statystyczny. Zakład Wydawnictw Statystycznych. Warszawa, 605.

28. Kupiec J. and Zbierska J. 2012. Comparison of Results obtained on the basis of selected types of nitrogen balance in the scale of a field and a farm. Polish Journal of Environmental Studies, 21(5).

29. Niklewski B. 1949. Nawożenie roślin na ziemiach polskich cz. I i II. Instytut Naukowo-Wydawniczy Ruchu Ludowego "Polska", Poznań, 473.

30. Górski M. 1947. Nawozy organiczne. Wyd. Insty- 
tutu Nauki i Oświaty Rolniczej. Warszawa, 190.

31. Rozporządzenie Rady Ministrów z dnia 18 maja 2005 r. zmieniające rozporządzenie w sprawie szczegółowych warunków i trybu udzielania pomocy finansowej na dostosowanie gospodarstw rolnych do standardów Unii Europejskiej objętej planem rozwoju obszarów wiejskich. Dz.U. 2005 nr 93, poz. 778, 779 i 780.

32. Wrześniowski Z., Sosnowska W., Stempel R. 1997. Tabele pomocnicze do planowania rolniczej działalności gospodarczej. Wyd. ART, Olsztyn, 112.

33. Stutzer A. 1902. Nauka o nawozach. Krótkie wskazówki o własnościach i użytkowaniu nawozów używanych w rolnictwie. Wyd. Redakcyi Rolnika i Hodowcy. Warszawa, 139.

34. Kostrowicka I., Landau Z., Tomaszewski J. 1984. Historia gospodarcza Polski XIX i XX wieku. Wyd. Książka i Wiedza. Warszawa, 577.

35. F.R. Rolnik Nadwiślański 1900. Kanalizacya miasta Warszawy jako narzędzie judaizmu szarlataneryi w celu zniszczenia rolnictwa polskiego oraz wytępienia ludności słowiańskiej nad Wisłą. Druk W. L. Anczyca i Spółki. Kraków, 37.

36. Zużycie energii w gospodarstwach domowych w 2009 r. (2012). Informacje i opracowania statystyczne. Główny Urząd Statystyczny. Warszawa, 136.
37. Topolski J. 1969. Wielkopolska jako region historyczny. [In:] J. Topolski (Ed.) Dzieje Wielkopolski do roku 1793. Wydawnictwo Poznańskie, Poznań 1, 23-30.

38. Włodarczyk J. 2012. Krainy historyczne Polski. Wyd. ARTI, Warszawa, 144.

39. Baranowski B. and Topolski J. (Eds.). 1964. Zarys historii gospodarstwa wiejskiego w Polsce, t. II. Państwowe Wyd. Rol. i Leśne. Warszawa, 600.

40. Kraciński P. 2011. Rozdysponowanie Własności Rolnej Skarbu Państwa w latach 1992-2009. Zesz. Nauk. SGGW. Warszawa, 87, 41-53.

41. Grzebisz W., Diatta B., Popp T., Szczepaniak W. 2004. Potas w produkcji roślinnej. IPI Basel/Switzerland, 88 .

42. Toczyński T., Wrzaszcz W., Zegar J.S. 2013. Zrównoważenie polskiego rolnictwa. Powszechny Spis Rolny 2010. Warszawa, 219.

43. Godlewski E. 1901. Pogadanka o pokarmach roślinnych. O nawozach sztucznych. Wyd. Groszowe im. Tadeusza Kościuszki, Kraków, Rok VIII. Serya II, Książeczka 34, 128.

44. Langie K. 1920. Nawozy pomocnicze, sztuczne i zielone. Praktyczny podręcznik dla rolników, leśników i szkół rolniczych. Drukarnia Ludowa w Krakowie. Biblioteczka Rolniczo-Przemysłowa, 3, 35. 